\title{
Measuring the Effect of the Quality Management System on the Export of Small Production Units (Case Study: Standards and Industrial Research Office of Semnan Province)
}

\author{
Mohammadali Ariamanesh', Hadise Fouladi ${ }^{2}$ and Hakimeh Khatoun Ariamanesh ${ }^{3}$ \\ ${ }^{1}$ Master of industrial Management \\ ariyamanesh.mim92@gmail.com \\ ${ }^{2}$ Master of Mathematical Statistics \\ Fooladihadis@yahoo.com \\ ${ }^{3}$ Master of Business Administration \\ Haria1352@gmail.com
}

Article history:

Received date: 18 October, 2019

Review date: 07 November 2019

Accepted date:26 December 2019

\section{Keywords:}

Quality Management System, Export, Small Production Units, Office Of Standards And Industrial Research of Semnan Province

\begin{abstract}
The purpose of this study was to identify ways to increase exports by measuring the effect of the quality management system. The question is; how much effect the establishment of quality management system has in production and industrial units? This is an applied research study, and method is descriptive-survey. The statistical population is consisted of small industrial units under supervision of the General Department of Standards and Industrial Research in Semnan Province. Data have been collected by using a researcher questionnaire containing 26 questions and were distributed among quality control authorities and representatives of the Office of Standards and Industrial Research of Semnan production units for a total of 40 units. Validity was confirmed according to the professors, experts and based on compatibility and reliability was confirmed based on Cronbach's alpha coefficient and through a sufficient number of respondents confirmed prior to the test. Inferential statistics was used for hypothesis testing normality using the Kolmogorov-Smirnov statistic $(k s)$ and t-test was used to examine the relationship between variables. The results suggest the establishment of a quality management system has effect on indicators exports, commodity prices, international standards, increase sales and durable goods indexes. But this system was not effective on the training and motivating of human resources and it had no significant difference.
\end{abstract}

Please cite this article as: Ariamanesh MA,. Fouladi H,. Ariamanesh HK. 2020. Measuring the Effect of the Quality Management System on the Export of Small Production Units (Case Study: Standards and Industrial Research Office of Semnan Province). SRPH Journal of Applied Management and Agile Organisation Volume 2, Number 1: (11-24)

\section{Introduction:}

Export is one of the most vital sectors which constitute economy of any country. Exports of goods and services are the country's most important source of foreign exchange earnings that the pulse of the economy of the world's alive and active in his hand. By increasing the volume of exports, diversify export products or export target markets can be developed (Ghareche and Shamshiri, 2010). Quality without clear definition of standard cannot be defined and measured. As the basic standard for measuring the quality that they are relying on customer expectations, quality can be determined. The use of standards reduces many affairs of which are lack of efficiency and effectiveness, and the best and the easiest way to introduce an activity (Heras Saizarbitoria and Boiral, 2013). The establishment of quality management systems and business excellence models, in order to standardize the methods and refine existing procedures special attention should be given to human resources (Abbasi and Amiri, 2009). Standard is valid criterion for assessment. So without standard the evaluation is not possible (Ebrahimi, 1997). ISO 9001 standard is a set of conditions in order to quality management system, regardless of the field of activity, size of the organization, and whether

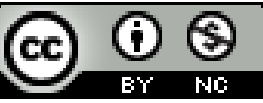


privately owned or public activity. These standards are the only kind of standard that does not care for the type of organizations (Karthi et al, 2011). Senior management organization based on the principles of quality management ISO 9001 series use as a framework to guide their organizations towards improved performance (Sitkillkay and Aslan, 2012).

The purpose of this study was to identify ways to increase exports by measuring the effect of the quality management system. In simple words, quality can be expected to mean a set of specifications that satisfy the client of products or services and quality management system is that part of the organization's which focuses on management system achieving results of quality objectives to meet the needs, expectations and requirements of interested parties or demands. If the main objectives of the establishment of ISO 9000 standards is to improve product quality, reduce cost, increase competitiveness and market share in the world's development, mainly in the country's output is not satisfactory. Unfortunately by implementing ISO 9000 standards the benefits and their results will be questioned. The organization must consider quality issue as a strategic category. However, the establishment of quality management systems from the outset in the country has promotional use. The main purpose of the establishment of management systems, profitability and customer satisfaction is a competitive and global market. Therefore in the country by making appropriate organizational culture, to motivate employees, improve the quality of management, changes in strategic thinking and old ways of changing the structure established quality. In this study, given the low rate of exports in small production units, lack of exercise or lack of the correct use of integrated systems of quality management as the main problem and the effect of whether or not the correct use of the system assessed the export of small production units and raise this question that; what is the effect of establishment of quality management system in production and industrial units on exports?

\section{Research theoretical framework:}

In the 1950s, Japanese products in the world included two outstanding features, low quality and low prices. The Japanese successfully addressed the root causes of the deviation and problem and what the commodity produced and anywhere they found a deviations and errors in the process or product design or distribution and after-sales service they quickly fell to the root of deviation and error and did not reprimand the person. Now the philosophy of total quality management is implemented in most countries is and they reached good results but according to scientists, the quality of the science must be localized in each country because culture and confidence of senior management is critical to the success or failure of the implementation of this philosophy (Evans and Lindsay, 2008).

Deming philosophy focus on improving production process quality and process design and production process by reducing the change. Deming's philosophy change is the main cause of low quality. Deming stated; "to cut down on change, we should follow an infinite cycle including product design, manufacturing, testing and selling in the market and redesign". He claimed that enhancing the quality brings profitability and, it will cause increase in the competition power.

Juran was more focused on the customer, from his perspective organizations need to reduce the cost of quality. This is completely different with Deming's approach because it ignores the cost of quality. Juran define quality as "suitable for use" and he believes that by measuring and solving quality problems, it can be a huge savings in costs. Money is a mean for management and the cost of poor quality can be measured in the form of inspection costs and costs of prevention. This process can help companies prioritize issues to improve the quality and deploy them into a routine project to project is to achieve improved systems and processes (Rajabbeihi and Salimi, 2012). Juran (1999) to check Xerox quality used a triple approach (planning, quality control and quality improvement) and knows senior management responsible for annual planning and providing sufficient funds for its implementation quality. Juran knows managers the cause of quality problems and believes that optimal production and better service requires awareness of the role of managers and it will determine the quality of products and services (Juran, 2000).

In Crosby perspective managers must continue to increase the quality to be able to compete. This reasoning led to Crosby's famous claim: (Quality is free). Crosby by development of this view believes that the key to improving the quality of management thinking is changing. 
Crosby knew four factors in achieving certain quality, these four factors are:

1. The definition of quality: making or needs

2-Prevention system

3- Components standard: the perfect job

4-Criteria: Quality Price

\section{The evolution of quality:}

The first stage in 1950 and 1957, the mission of quality in the industry was to separate the items optimum production from pool production at this stage of simple tools known as 7 statistical devices (Circulating charts, flow chart, control charts, sheet inspection, diversion mode, diagrams Pareto and scattering diagram) was used. The second stage in 1957 and 1970 was the mission of quality in the industry and focus on the production process and prevent production of faulty products during the manufacturing process at this stage by using 7 tool tools such as regression statistics, modeling, experimental design (DOE) and others. Third stage: In 1970 to 1980, the mission was to focus on quality of design and planning. The fourth stage in the years 1980 to 1990 , the mission was to emphasize quality, marketing, after-sales service and estimate requests and customer requirements, at this stage, while employing all available means of tools such as mechanisms of high quality (QFD) and predict failure modes and failure analysis (FMEA) was also used (Ross, Joel Wood, 1390).

\section{Total Quality Management:}

Total platform quality management and Field Dictionary defines quality as follows: When we use the term quality is often superior to the terms of a product or service that we think will meet our expectations or it outpaces and the expectations and the application product is based on the sale price (Saghaei and Shekari, 2010). International Organization for Standardization ISO 1987 define quality as all the features and characteristics of a product or a service that provides implicit and explicit needs. Joseph Juran believed that quality involves some of the characteristics of goods produced or services provided, which is estimated the needs and desires of the organization to provide. In the study, 86 managers of the US were asked to define quality. The following were some of the definitions provided and mentioned in order of frequency; 1 - Perfect job without fallacies 2-strength 3-removing waste 4-speed delivery of 5-compatible with the policies and procedures 6-producing applicable goods 7-doing the job correctly from the beginning to end 8- making customer happy and satisfying them 9- providing full service to customers and satisfying them (Pardakhtchi et al, 2009). Given the competitiveness of global market, now companies are trying manufacturing and service organizations their products and services with superior quality and reasonable price than the market so that they can thereby increase customer satisfaction and to allocate a greater share of the consumer market. Thus for achieving the global targets in relation to the products offered by the organization when it is possible that serious efforts for continuous improvement in all aspects of product performance comes into action. In other words, the most basic step in order to achieve superior quality and reduce production costs and service delivery, is reviewing and improving work processes. In this a real competition only one track is created through the continuous expansion of the advantages of competing at a higher level of organization (Olia and Shishebori, 2011).

\section{Quality management system:}

Quality management can monitor the product's manufacturing process to ensure product compliance with what the designer intended or customer (Mendoza, 2013). Since this monitoring includes process and orders the raw materials to after-sales services therefore it covers a range of activities such as accessibility, convenience of transportation, low power consumption and ease of training (Rezaei et al, 2011). On the other hand, you can also use products as well as maintenance and utilization of quality factors. In this connection, human resources have important roles to improve the quality of services provided by the organization or industry. Given that the human resources do the work of an organization; therefore, their involvement is crucial for the realization of quality improvement (Goetsch and Davis, 2013). Quality management has 8 principles to facilitate the achievement of targeted quality. The emphasis on each of the eight principles is 
very valuable and helpful. These principles can meet the demands of present and future customer orientation that includes internal customers (employees) and the principle of participation, which includes providing the features and capabilities of the employee's conditions. The spirit of an organization is used for full engaging in the affairs of the organization for all the capabilities and capacities of people to achieve the organization's interests. Implementation of these principles will increase customer satisfaction (external and employees) and will have motivation, commitment and passion to contribute to the continuous improvement of the organization. There are different models for establishing quality management systems (Sitki, Ilkay and Aslan, 2012). McKenna suggests that organizations in order to achieve satisfied customers, should check out the market, forgot advertise and promote the development of appropriate infrastructure and the customer's response and to achieve true satisfaction (Mckenna, 1991).

\section{ISO 9001 standard:}

Considering the significant progress of science, technology, communication and transportation, domestic and international trade, exchange of information on the global markets through this rapid movement of goods using advanced means of communication and transportation, the impact of commodity trading and services on the environment, trade, intellectual property rights and to has been established new relations in the international trade industry. In today business new technologies are proposed such as "top quality" and "customer satisfaction" no producing to sell more. Over time, to reassure customers about the quality of goods and services supplied to him and his satisfaction the methods of quality assurance were developed and implemented (Montaghemi, 2006). ISO 9001 series of standards was presented to the world in 1978 by 176 Technical Committee of International Organization for ISO (Karapetrovic et al, 1998) that were revised in 1994, 2000 and 2008. The requirements of this standard have five main headings (Baldassarre et al, 2011). The aim of these standards is establishing international model for implementation and deployment of the quality management system and quality assurance. Quality management systems are defined in order to maintain quality levels and implemented quality improvement through process improvement organization (Abdullah et al, 2011). Benefits of quality management system in an organization are not limited only to earn customer trust and achieve greater market share but it will bring many benefits to the organization management (Rusko et al, 2014). Some of it can be summarized as:

1- Improving the planning, organization and control of the organization by effectively and efficiently managing marketing

2- Increasing the number of customers.

3. Raising the level of customer satisfaction through more confidence and provide better service for them

4. Imposing effective controls on the process

5. Reducing costs, waste, duplication and errors

6. Improving the quality and delivery of services (Tamic et al, 2012).

Most current version quality management systems such as ISO standard 9001 organization focused on the effectiveness of processes (Kull and Narashiman, 2010). Accepting a quality management system should be considered as a strategic decision-making in the organization. Designing and implementation of an organization's quality management system is influenced by several factors, including different needs, specific objectives, products, used processes, size and structure of the organization (Zhang et al, 2014). Certain requirements of this international standard for a quality management system are complementary requirements related to product. The international standard in the process of developing, implementing and improving the effectiveness of the quality management system, process-oriented perspective, encourages organizations to select to meet the requirements of the customer and increase customer satisfaction. Once such an approach in a quality management system is used, the following cases are being emphasized; 1 Understanding and meeting the requirements 2- requiring processes in terms of added value 3- outcomes performance and process effectiveness 4- continuous improvement processes based on point measurements (Myhrberg and Gordon, 2010). 


\section{Indicators of Quality Management System:}

Shankle (2004) showed that ISO 9001 is a competitive advantage for of basic needs and a weakness in shortage cases. Therefore, ISO 9001 transformed into one of organizations definitive documentary requirements for success. Main indicators for quality management system in ISO 9001 policy can be summarized as follows:

Skills and experience: using highly qualified, experienced and creative highlights the need for skills in human resources. Staff training shows the attention to the role of knowledge in order to carry out the tasks. Finally, promoting participation and encouraging teamwork is effective in motivating people (Zhang, 2007). Education: is a planned effort by an organization to facilitate learning and is applied to job-related behavior on the part of employees. The overall objectives of education and improvement are: 1-increase the ability and personal growth of employees to improve their performance 2-teaching new skills rather than obsolete skills 3-improve the knowledge, attitudes and skills appropriate to their organizational career 4-enhancing skills and people knowledge to promote. Teamwork: In order to achieve the goal, people in groups of two or more people interact regularly with each other and coordinate their actions (Magd and Nabulsi, 2012). Creativity: the ability to integrate the idea into a unique manner, for unusual communication between different ideas and creativity that is a function of the degree of willingness. The importance of innovation is such that only the organizations can continue their work in today's competitive world that through creative staff, apply new ideas and constantly thinking. Employee participation: when the employee is given an opportunity to show their abilities, their satisfaction level and the effectiveness of the technology will increase (Zhang, 2007). The main reasons that are common in the participation and commitment of staff a result of quality management and a sense of ownership in decision-making are: 1- Information and lot of skill evolving categories such as increasing quality, identifying problems and improving work processes 2trying to make higher quality decision. Managers must understand that always participation is not appropriate, know decision-making areas as a chance to hear employees' participation (Verom and Yetton, 1973).

ISO 2000 to ISO 9000 is a degree of meeting the requirements by the inherent characteristics set (Saghaei and Shekari, 2010). It is one of categories affecting production, trade and export of goods, standardization of goods and services. Standard influences international trade and export from different angles. Some of the effects include: 1- the effect of the standard on international transactions 2-facilitate and expand trade exchanges 3-Ease assess to the damage caused by the carriage of goods 4-enhancing the quality of export products in consumer confidence 5- Other standard benefits and their impact on exports (the standard product to save in the design, manufacturing, warehousing and transportation of goods leads, as a result of favorable ground for the use of resources to produce more and increase exports) 6- The effect of product standards and production practices on export (the importance of standards and their role in promoting quality, product safety and trade led to the development of product and process standards in various areas, in addition, developed countries, other countries by taking advantage of technological advances to national and international standards benefit their interests.) 7-The effect of packaging and labeling standards 8- standards and health regulations and plant quarantine and export 9- the effects of barcode on the export of goods (Montaghemi, 2006).

\section{Review of Literature:}

Hoshiar (2008) in a study entitled evaluate the readiness of university administrators to deploy a quality management system in Ferdowsi University of Mashhad has concluded that being prepared is very important for the establishment of a comprehensive quality management system and at the University of above is average (Hoshiar, 2008). Sarafrazi and Memarzadeh (2008) in a study entitled The Establishment of a comprehensive quality management system and its role in improving customer satisfaction with population $\mathrm{N}=1200$ executives concluded that there is a significant relationship between the establishment of a comprehensive quality management system and increasing customer satisfaction which in their case it is average toward clients satisfaction and believe that to satisfy customers and the majority of employees that senior management in their organizations they should improve the quality of programs and activities in moderate to high support (Sarafrazi and Memarzadeh 2008). Nouhpishe (2005) in a study entitled the 
establishment of quality management systems in the Department of Education show that organizational readiness for the establishment of quality management system is average (Nouhpishe, 2005). Riahi (2009) in a study entitled National Quality Management System exports concluded that developing a national system of quality management in order to maintain the country's export target markets and identifying new markets it is serious and unavoidable and all relevant organizations must be sensitive toward it (Riahi, 2009). Ranjbarian et al (2012) in a study entitled Analysis of the relationship between perceived quality, perceived value, customer satisfaction and repurchase intention in Tehran chain stores concluded that in chain stores, perceived quality affects perceived value and customer satisfaction and repurchase intention, in addition to its perceived value on customer satisfaction and repurchase intention is effective (Ranjbarian et al, 2012). Khakrangin (2013) in a study entitled Effect on service quality, relationship marketing, relationship quality and customer loyalty has found that the impact on service quality, relationship marketing, customer relationship and loyalty is positive (Khakrangin, 2013). Kafashpour et al (2010) in a study entitled impact on organizational performance through market-driven Total Quality Management concluded that the results of previous studies on the positive effects on the performance of market-based approaches of Total Quality Management but analysis revealed that the two systems in parallel organization in the central market impact of total quality management on the performance and quality of service, did not play a mediating role (Kafashpour et al, 2010). Ghareche et al (2010) in a study entitled Benefits of export management companies in the small business export development strategies concluded that many of the problems that enterprises, especially small and medium enterprises in export and international business are faced have financial or information nature at first, it should be to identify needs and create demand for manufactured products of small and medium enterprises and these activities are mostly have information aspect and in process and respond to the created demands and products in accordance with identified needs of foreign markets help firms and this aspect of activities has financial and management aspect (Ghareche and Shamshiri, 2010). Khanarinejad and Nadighora (2013) in a study entitled Study and establishment of a comprehensive quality management system at Mazandaran University of Medical Sciences and Health Services concluded that in statistical population $\mathrm{N}=280$ samples implementation of quality management systems with an average of 4.012 and difference with mean of 3 in Likert scale is meaningful and acceptable at this university (Khanarinejad and Nadighora, 2013).

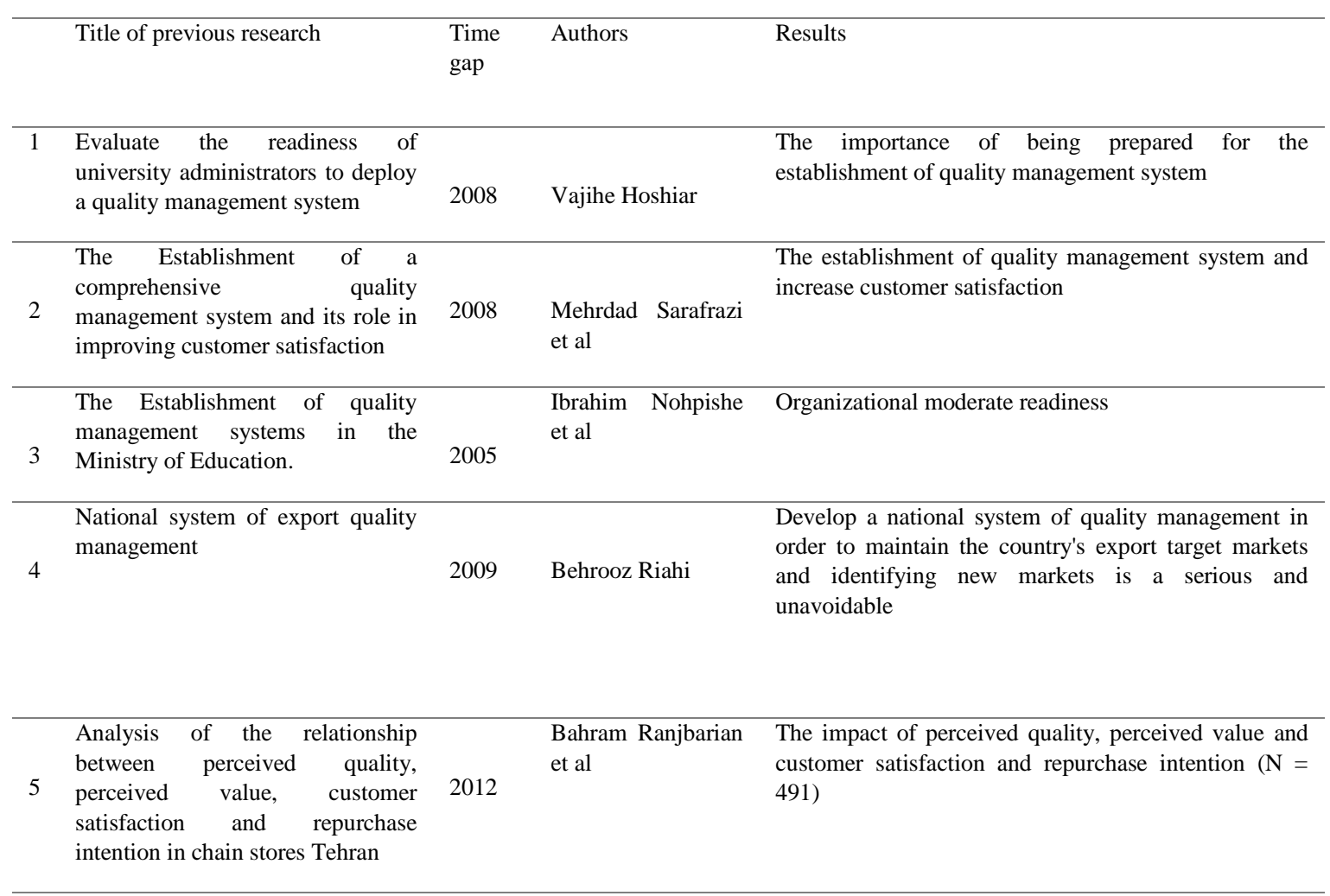




\begin{tabular}{|c|c|c|c|c|}
\hline 6 & $\begin{array}{l}\text { The effect on service quality, } \\
\text { relationship } \\
\text { relationship quality and customer } \\
\text { loyalty }\end{array}$ & 2013 & Vida Khakrangin & $\begin{array}{l}\text { Positive impact on the quality of relationship } \\
\text { marketing services, prices, durable goods, and live } \\
\text { customer relationship }(\mathrm{N}=400)\end{array}$ \\
\hline 7 & $\begin{array}{l}\text { Impact of Total Quality } \\
\text { Management on Organizational } \\
\text { Performance by the central market }\end{array}$ & 2010 & $\begin{array}{l}\text { Azar Kafashpour et } \\
\text { al }\end{array}$ & $\begin{array}{l}\text { Influence positively the quality and market-oriented } \\
\text { approach to performance management, but analysis } \\
\text { revealed that the two systems in parallel, } \\
\text { organizational central market impact of quality } \\
\text { management on the performance and quality of } \\
\text { service, could play a mediating role. }(\mathrm{N}=45)\end{array}$ \\
\hline
\end{tabular}

\begin{tabular}{|c|c|c|c|c|}
\hline 8 & $\begin{array}{l}\text { Advantages of using Export } \\
\text { Management Co in small business } \\
\text { export development strategies }\end{array}$ & 2010 & $\begin{array}{l}\text { Manije Ghareche et } \\
\text { al }\end{array}$ & $\begin{array}{l}\text { Helping firms to produce in accordance with identified } \\
\text { needs foreign markets, financial aspects and } \\
\text { management. }(\mathrm{N}=60)\end{array}$ \\
\hline 9 & $\begin{array}{l}\text { Study and establishment of a } \\
\text { comprehensive quality } \\
\text { management system in } \\
\text { Mazandaran University of Medical } \\
\text { Sciences and Health Services }\end{array}$ & 2013 & $\begin{array}{l}\text { Azizolah } \\
\text { Khanarinejad et al }\end{array}$ & $\begin{array}{l}\text { Implementation of quality management system at the } \\
\text { University is meaningful and acceptable. }(\mathrm{N}=280)\end{array}$ \\
\hline
\end{tabular}

\section{Conceptual model of research:}

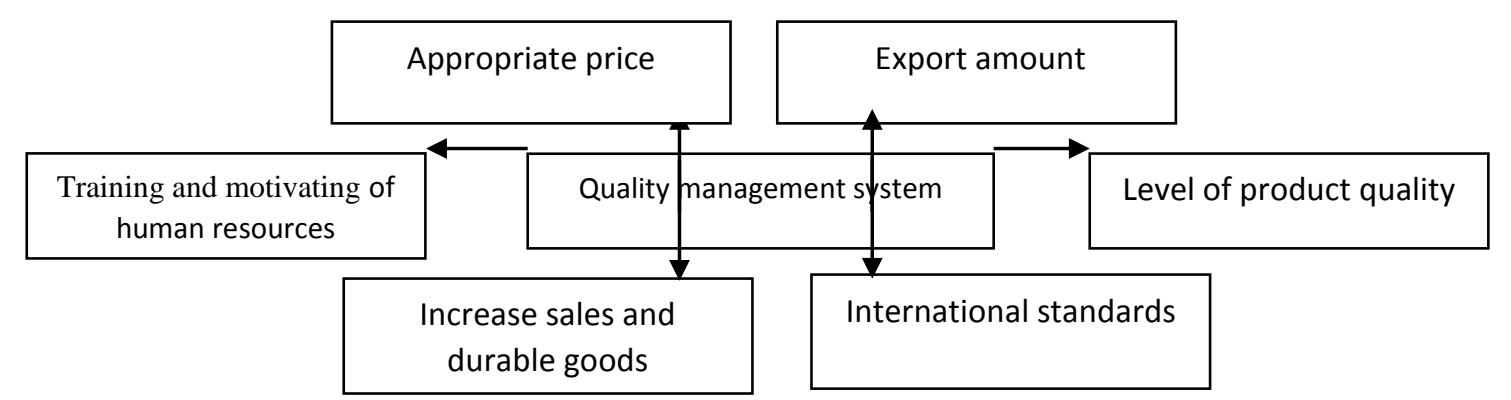

Conceptual Model of the Effect of Quality Management System (Source: Researcher)

\section{Research Hypothesis:}

Based on the conceptual model of research, hypothesis formulation is as follows:

1- The establishment of quality management system has effects on exports rate.

2- The establishment of quality management system has effects on commodity prices.

3- The establishment of quality management system has effects on goods quality.

4- The establishment of quality management system has effects on training and motivating of human resources.

5- The establishment of quality management system has effects on international standards.

6- The establishment of quality management system has effects on sales increase and durable goods.

To test the hypothesis, first the indicators of each hypotheses be specified and the mean of question will be calculated and t-test will be done on mean. The numerical value for the items are; very low, low, medium, high and very high that are respectively 1,2, 3, 4 and 5. Table 2 shows the mean of indexes.

\section{Methodology:}

The purpose of this study is based on an applied research and methods and it is descriptive and survey. The statistical population consisted of small industrial units under the General Department of Standards and Industrial Research Semnan. The reason for choosing this society is analyzing the importance of quality 
management system and export, from the views of representatives of the agency's quality control and with the permission of the Department, data through a researcher questionnaire containing 26 questions, were distributed among officials and representatives of the General Administration of Quality Control Standards and Industrial Research of Semnan production units that are a total of 40 units. Validity was approved by the professors and experts and reliability based on Compatibility according to Cronbach's alpha coefficient and through a pre-test on a sufficient number of respondents evaluated and the value of 0.90 is obtained and it can be said that the questionnaire is reliable. In this study two methods of survey (questionnaire and documents) and library (related books, articles and internet) were used which is based on the aspects and issues related to information studies and various levels investigated and described in the literature review and then using field studies to collect data and information in order to measure the application of quality management system on the export of small production units of Standard and Industrial Research of Semnan. The descriptive statistics including frequency, frequency percentage and outlining charts of qualitative and quantitative information has been extracted and it is continued with use of statistical inference and assumption of normality after the evaluation of the data using the Kolmogorov-Smirnov test (ks) in SPSS 21 statistical software to evaluate hypotheses and t-test was used.

\section{Statistical population:}

Office of Standards and Industrial Research of Semnan since 1992 with the launching and completing its labs in the areas of: food industry, microbiology, chemical, packaging and cellulose, safety and performance counters, gas appliances, non-stick cookware, stigma Precious Metals, calibrated and weights and measures, electrical industry, sanitary valves, construction and textile industries and production samples tested the undercover units. The statistical population consisted of small industrial units covered by this administration and a questionnaire containing 26 questions (designed by researcher) were distributed and collected among officials and representatives of the General Administration of Quality Control Standards and Industrial Research of Semnan production units which is a total of 40 people. The reason for choosing this community is the importance of quality management systems and quality control inspectors export in representatives views.

\section{Data analysis:}

In Table (2)- the results of Kolmogorov-Smirnov test (ks) were provided, as it can be seen in the normal distribution assumption significance level 0.05 ( $\mathrm{sig}>0.05$ ) has been accepted, therefore, in order to test the impact of assumptions on factors of quality management systems in exports, commodity prices, the level of product quality, training and motivation of human resources, international standards, sales increase and durable goods t- test parameter was used and the results are summarized in following table;

Table 2: Results of Kolmogorov-Smirnov test of understudy variables:

\begin{tabular}{|c|c|c|c|c|c|}
\hline Export rate & $\begin{array}{l}\text { Commodity } \\
\text { prices }\end{array}$ & $\begin{array}{l}\text { Quality } \\
\text { level of } \\
\text { good }\end{array}$ & $\begin{array}{l}\text { Training anc } \\
\text { motivating } \\
\text { workforce }\end{array}$ & $\begin{array}{l}\text { International } \\
\text { standards }\end{array}$ & $\begin{array}{l}\text { sales increase And } \\
\text { durable goods }\end{array}$ \\
\hline
\end{tabular}

\begin{tabular}{lcccccc}
\hline Sample size & 40 & 40 & 40 & 40 & 40 & 30 \\
\hline Mean & 3.26 & 3.28 & 3.2 & 3.08 & 3.33 & .53 \\
\hline $\begin{array}{l}\text { Standard } \\
\text { deviation }\end{array}$ & .60 & .76 & .63 & .52 & .51 \\
\hline $\begin{array}{l}\text { Kolmogorov- } \\
\text { Smirnov }\end{array}$ & .98 & .93 & .74 & 1.00 & .61 & .62 \\
\hline Sig level & .28 & .34 & .64 & .26 & .84 & .82
\end{tabular}


The in the discussion of presented hypotheses and the mean of questions relating to the Index under investigation was calculated and as it can be seen in Table 3, the population size $(n=40)$ and Impact on the Quality Management System exports mean, standard deviation and standard deviation of the mean error is calculated and they are respectively, 3.26, 0.60 and 0.09. Also for the index of impact on commodity prices as well as for the Quality Management System average (3.28), standard deviation (0.76) and the mean error standard deviation (0.12) is obtained. Also for the index of impact on the quality of the product as well as quality management system average (3.24), standard deviation (0.63) and the mean error standard deviation (0.09) is calculated. Index values of descriptive statistics on the impact of training and motivating of human resources quality management system on average (3.08), standard deviation (0.52) and the mean error standard deviation (0.08) and the impact of international quality management system standards mean, standard deviation and the standard deviation to the mean error of $3.33,0.53$ and 0.08 , and the index of the impact of the quality management system to increase sales and durable goods with mean, standard deviation and standard deviation of the mean error, respectively are, 3.30, 0.51 and 0.08 .

Table 3 - Descriptive statistics of understudy variables:

\begin{tabular}{|c|c|c|c|c|}
\hline Understudy variables & $\begin{array}{l}\text { Sample } \\
\text { size }\end{array}$ & Mean & $\begin{array}{l}\text { Standard } \\
\text { deviation }\end{array}$ & $\begin{array}{l}\text { Standard deviation of } \\
\text { mean error }\end{array}$ \\
\hline The effect of establishment of quality management system on exports rate & 40 & 3.26 & .609 & .096 \\
\hline $\begin{array}{l}\text { The effects of establishment of quality management system on commodity } \\
\text { prices }\end{array}$ & 40 & 3.28 & .767 & .121 \\
\hline The effects of establishment of quality management system on goods quality & 40 & 3.24 & .631 & .099 \\
\hline $\begin{array}{l}\text { The effects of establishment of quality management system on training and } \\
\text { motivating of human resources }\end{array}$ & 40 & 3.08 & .520 & .082 \\
\hline $\begin{array}{l}\text { The effects of establishment of quality management system on international } \\
\text { standards }\end{array}$ & 40 & 3.33 & .533 & .084 \\
\hline $\begin{array}{l}\text { The effects of establishment of quality management system on sales increase } \\
\text { and durable goods }\end{array}$ & 40 & 3.30 & .519 & .082 \\
\hline
\end{tabular}

In first hypothesis it was claimed that "The establishment of quality management system has effects on exports rate." According to Table (4) the test statistic ( $\mathrm{t}=2.76)$ is provided. Due to the significant level obtained (sig $=0.009<0.05$ ) the H0 (non-effective) is rejected, it mean with $95 \%$ certainty that the quality management system is affecting exports. The difference of mean sample with tested value is 0.26 and $95 \%$ certainty interval ( 0.46 and 0.07 ) in other words; the mean is bigger than value test and with certainty it can be said that the establishment of quality management system leads to an increase in exports.

The second hypothesis claims that the establishment of quality management system has effects on commodity prices. According to Table (4) the test statistic $(\mathrm{t}=2.37)$ is provided. Due to the significant level obtained (sig=0.023 $<0.05$ ) the H0 (non-effective) is rejected, it mean with $95 \%$ certainty that the quality management system is affecting exports. The difference of mean sample with tested value is 0.26 and $95 \%$ certainty interval ( 0.53 and 0.04$)$ in other words; the mean is bigger than value test and with certainty it can be said that the establishment of quality management system leads to an increase in commodity prices.

The third hypothesis claims that the establishment of quality management system has effects on goods' quality level. According to Table (4) the test statistic ( $\mathrm{t}=2.42)$ is provided. Due to the significant level obtained (sig=0.02<0.05) the H0 (non-effective) is rejected, it mean with $95 \%$ certainty that the quality management system is affecting exports. The difference of mean sample with tested value is 0.26 and $95 \%$ certainty interval ( 0.44 and 0.03$)$ in other words; the mean is bigger than value test and with certainty it can be said that the establishment of quality management system leads to an increase in goods' quality level. 
Table (4): The results of a sample of student t-test:

\begin{tabular}{|c|c|c|c|c|c|c|}
\hline \multirow[t]{2}{*}{ Understudy variable } & \multirow[t]{2}{*}{ t-statistic } & \multirow{2}{*}{$\begin{array}{l}\text { Degree of } \\
\text { freedom }\end{array}$} & \multirow[t]{2}{*}{ Sig level } & \multirow{2}{*}{$\begin{array}{l}\text { Mean } \\
\text { difference }\end{array}$} & \multicolumn{2}{|c|}{$95 \%$ certainty level } \\
\hline & & & & & Low & High \\
\hline $\begin{array}{l}\text { The effects of establishment of quality } \\
\text { management system on export rate }\end{array}$ & 2.76 & 39 & .009 & .26 & .071 & .46 \\
\hline $\begin{array}{l}\text { The effects of establishment of quality } \\
\text { management system on commodity prices }\end{array}$ & 2.37 & 39 & .023 & .28 & .042 & .53 \\
\hline $\begin{array}{l}\text { The effects of establishment of quality } \\
\text { management system on goods quality }\end{array}$ & 2.42 & 39 & .020 & .24 & .039 & .44 \\
\hline
\end{tabular}

The fourth hypothesis claims that the establishment of quality management system has effects on training and motivating of workforce. According to Table (5) the test statistic $(\mathrm{t}=1.06)$ is provided. Due to the significant level obtained (sig=0.29>0.05) the H0 (non-effective) is confirmed, it mean with $95 \%$ certainty that the quality management system is affecting training and motivating of workforce. The difference of mean sample with tested value is 0.08 and $95 \%$ certainty interval $(0.25$ and -0.078$)$ in other words; the mean is smaller than value test and with certainty it can be said that the establishment of quality management system leads to decrease the quality of training and motivating of workforce.

The fifth hypothesis claims that the establishment of quality management system has effects on international standards. According to Table (5) the test statistic $(\mathrm{t}=0.4)$ is provided. Due to the significant level obtained ( $\mathrm{sig}=0.00<0.05$ ) the $\mathrm{H0}$ (non-effective) is rejected, it mean with $95 \%$ certainty that the quality management system is affecting international standards. The difference of mean sample with tested value is 0.08 and $95 \%$ certainty interval $(0.50$ and 0.16$)$ in other words; the mean is bigger than value test and with certainty it can be said that the establishment of quality management system leads to increase in the quality of international standards.

The sixth hypothesis claims that the establishment of quality management system has effects on sales increase and durable goods. According to Table (5) the test statistic $(\mathrm{t}=3.65)$ is provided. Due to the significant level obtained ( $\mathrm{sig}=0.001>0.05$ ) the $\mathrm{H} 0$ (non-effective) is rejected, it mean with $95 \%$ certainty that the quality management system is affecting sales increase and durable goods. The difference of mean sample with tested value is 0.30 and $95 \%$ certainty interval $(0.13$ and 0.46$)$ in other words; the mean is bigger than value test and with certainty it can be said that the establishment of quality management system leads to increase in sales increase and durable goods.

Table (5): The results of a sample of student t-test:

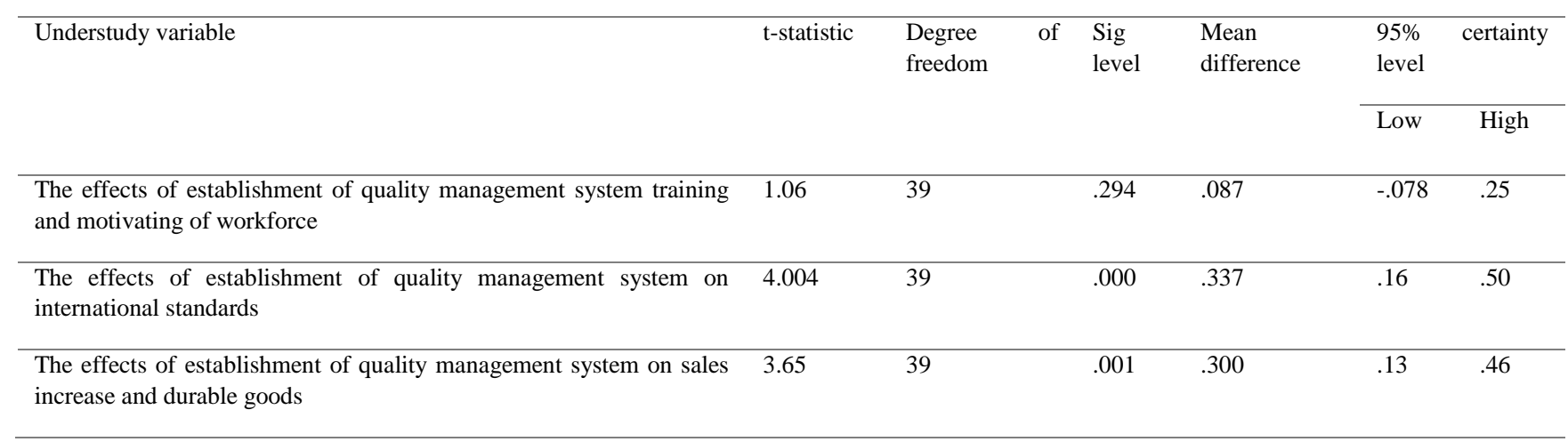

\section{Discussion:}

In response to the first hypothesis to test the effectiveness of the quality management system on the exports, the hypothesis is confirmed, that can be said with certainty that the establishment of quality management 
system leads to an increase in exports which is consistent with results of Hoshiar (2008), Sarafrazi et al (2008), and not consistent with studies of Nuhpishe et al (2005).

In response to the second hypothesis to test the effectiveness of the quality management system on the commodity prices, the hypothesis is confirmed, that can be said with certainty that the establishment of quality management system that have effect on commodity prices which is consistent with results of Khakrangin (2013).

In response to the third hypothesis to test the effectiveness of the quality management system on goods' quality, the hypothesis is confirmed, that can be said with certainty that the establishment of quality management system have effect on goods' quality which is consistent with results of Khakrangin (2013) and is not consistent with Kafashpour et al (2010).

In response to the fourth hypothesis to test the effectiveness of the quality management system on training and motivating of workforce, the hypothesis is confirmed, that can be said with certainty that the establishment of quality management system has no effect on teaching and motivating of workforce which is consistent with results of Nouhpishe et al (2005) and it is not consistent with Ranjbarian et al (2012).

In response to the fifth hypothesis to test the effectiveness of the quality management system on international standards, the hypothesis is confirmed, that can be said with certainty that the establishment of quality management system have effect on international standards which is consistent with results of Riahi (2009) and it is not consistent with Gharecheh et al (2010).

In response to the sixth hypothesis to test the effectiveness of the quality management system on sales increase and durable goods, the hypothesis is confirmed, that can be said with certainty that the establishment of quality management system have effect on sales increase and durable goods which is consistent with results of Khakrangin (2013) and Khonarinejad et al (2013).

\section{Conclusion:}

The results showed that the establishment of quality management system has effect on indicators exports, commodity prices, and the level of product quality, international standards, increase sales and durable goods affects but it has no effect on training and motivating workforce and had a significant difference. It seems that sometimes the establishment of a comprehensive system of quality systems with innovative technologies in production units with a lack of acceptance and trust optimal faces and always considered the traditional and former approach. Thus increasing the quality level election systems, training, comprehensive and timely administrators and users' productive units could be increased efficiency and better compliance and motivation. To achieve the goal of quality, such as components of an organism's production units should coordinate different activities. In addition to a factory quality control, there are other units with different functions are an effective role in crop production. In other words, there is strong relationship between quality and multiple units and all the units in an organization so on affect product quality or service offered. Standardization of goods and services and the use of international standards for the establishment of appropriate quality systems in manufacturing plants and service benefits, including standard and its impact on improving product quality, successful sales, increased production and export companies and ultimately increase the country's exports. Experience has shown that companies that have been successful in exports following the motto "the customer is right" have tried the implementation of strategic planning for customer satisfaction. One of the most important activities for market success and customer satisfaction is improving the quality of goods and services and international certification of conformity of the product or system located at the company. If you have received prestigious international certificate of conformity of the product or system located at the company. Today superior quality goods and services along with other factors and conditions affecting export sales such as market conditions, the packing and distribution of goods and services after sales and export activities will be effective in achieving a result. The use of facilities for production and exportation of goods promotes the quality and values of export goods are exported. Successful export should be continued despite the conditions and standards of the importing country factors. The standard applies to the participation of all organizations in the country involved in manufacturing, regulatory and export needs. Thus, in collaboration with relevant organizations, trouble shooting, legal and 
administrative shortcomings and difficulties to export products and success in increasing the quantity and improving the quality level of exports will be possible. It is hoped to improve the quality of goods for export, thereby increasing the level of production in the world markets.

\section{Recommendations:}

Establishment of quality management system will help inspectors of in monitoring and detailed assessment of their series production and also set up correctly and to improve the quality of products and ultimately helps to increase exports of manufactured goods. Quality control managers of Standard and Industrial Research are recommended to build trust with adequate training on how to deploy this system and the importance of the manufacturing industry to ensure optimal utilization occur.

\section{References}

Abbasian Mohsen, Naghi Amiri, Ali (2009) Investigate the relationship between quality management system and employee productivity (National Company for distribution of petroleum products Qom region), the first national conference on new approaches to procurement, maintenance, transportation and distribution of petroleum products, Tehran.

Abdullah, S., Latiff, A. A., Paraidathathu, T., Jaafar, A., Ahmad, W. N. W., Hussein, S. M., \&Daud, S. (2011). Gap Analysis towards Harmonisation of the MQA Code of Practice for Programme Accreditation with the Quality Management System of MS ISO 9001: 2008. Procedia-Social and Behavioral Sciences, 18, 436-441.

Baldassarre, M. T., Caivano, D., Pino, F. J., Piattini, M., \&Visaggio, G. (2012). Harmonization of ISO/IEC 9001: 2000 and CMMI-DEV: from a theoretical comparison to a real case application. Software Quality Journal, 20(2), 309-335.

Department of State Bureau of Educational and promote planning and development (2011) portal institute standard and industrial research of iran. Retrieved from www.alborz.isiri.org.

Ebrahimi, P. (1997). Study of standard regards values in medical record department in hospitals of social security branches in Tehran (Doctoral dissertation, MSc thesis]. Tehran: Iran University of Medical sciences, school of management and medical information science).

Evaluate the quality and effectiveness of enterprise information systems (2010) Tehran, NAZARI publications.

Gharecheh, Manijeh; Shamshiri Fariborz (2010); Benefits of export management companies in the small business export development strategies.

Goetsch, D. L., \& Davis, S. B. (2013). Quality Management for Organizational Excellence: Introduction to Total Quality. Japan: Pearson Education International.

Heras-Saizarbitoria, I., \&Boiral, O. (2013). ISO 9001 and ISO 14001: Towards a research agenda on management system standards*. International Journal of Management Reviews, 15(1), 47-65.

Hoshiar, Vajieh (2008), Evaluate the readiness of university administrators to deploy a quality management) Community Case Study: Ferdowsi University of Mashhad

Institute of Standard and Industrial Research of Iran, the Office of Administrative modernization and transformation; 2008 quality management in industrial research .Tehran

Iranzadeh, Soleyman; Khalili, Majid, Retrieved from www.farabi.ac.ir (2014)

Joel, A. Ross (2011) Total Quality Management

juran, j. (2000). The relationship between total quality Management practices and their effects on firmperformance, journal of operations management.350-405.

Kafashpour, Azar; Zendedel, Ahmad; Khajei, Rozita (2010); Impact of Total Quality Management on Organizational Performance by the central market. P. www.sid.ir.

Karapetrovic, S., Rajamani, D. and Willborn, W. (1998). ISO 9001 Quality System: An Interpretation for the University, International Journal ofEngineering Education, 14(2): 105-118. 
Kardan, Fatemeh (2008), Experience in the area of quality management system, ISO9001-2000. Tehran: Center for Training and Industrial Research

Karthi, S., Devadasan, S. R., \&Murugesh, R. (2011). Lean Six Sigma through ISO 9001 standard-based quality management system: an investigation for research. International Journal of Productivity and Quality Management, 8(2), 180-204.

Khakrangin, Vida (2013) The effect on service quality, relationship marketing, relationship quality and customer loyalty.

Khonari Azizolah; Nadi Ghora, Asghar (2013); Check indicators and dimensions of comprehensive quality management system in Mazandaran University of Medical Sciences and Health Services.

Kull, T. J., \&Narasimhan, R.(2010). Quality management and cooperative values: Investigation of multilevel influences on workgroup performance. Decision Sciences, 41(1), 81-113.

Magd, H., \&Nabulsi, F. (2012). The Effectiveness of ISO 9000in an Emerging Market as a Business Process Management Tool: the case of the UAE. Procedia Economics and Finance, 3, .165-158

Mahdavi, A, Tarahzadegan, F (2010) Evaluate the quality and effectiveness of enterprise information systems. Tehran: Nazari

Mckenna, r;. (1991). relationship marketing: successful strategies for the customer.

Montaghemi, Forough (2006); Standard and exports. Tehran: Institute for Trade Studies and Research .s 102

Myhrberg, E. V. (2010). A Practical Field Guide for AS9100C.ASQ Quality Press.

Naeimi Ehsan; Soltanabad, Vahid (2014) The role of quality in industrial production, www.modiryar.com

Nouhpishe, Ibrahim (2005) The Establishment of quality management systems in the Department of Education. Master's thesis Islamic Azad University, Najaf Abad

Olia Mohammad Saleh, Shishehbori Davood (2011), Understanding the concepts and methods of quality management Yazd, Yazd University

Pardakhtchi, Mohammad Hasan, Ghahremani Mohammad; Goldosen Juibari, Yaser (2009) Quality of work life (the necessity of developing the employees in organizations) Tehran; BEHAVARAN.

Rajabbeigi, Mojtaba; Salimi Mohammad Hossein (2012); Comprehensive management, Information Center of Ministry of Sazndgy.thran: Amir Kabir University

Ranjbarian, Bahram; Rashid Kabolo, majid; Sanayei, Ali Hadadian, Alireza (2012) Analysis of the relationship between perceived value, perceived quality, customer satisfaction and repurchase intention in Tehran chain stores.

Rezaei, A. R., Çelik, T., \&Baalousha, Y. (2011).Performance measurement in a quality management system. Scientia Iranica, 18(3), 742-752.

Riahi Behrouz (2009), National system of export quality management, www.irsq.org

Riahi Behrouz (2009), Quality management in research centers of the country. Standard Institute faculty member.

Rusko, M., Sablik, J., Marková, P., Lach, M., \& Friedrich, S. (2014).Sustainable development, quality management system and environmental management system in Slovak Republic. Procedia Engineering, $69,486-491$.

Saghayi Abbas; Shekari Maryam (2010); statistical quality control. Tehran

Sarafrazi, Mehrdad; Memarzadeh, Gholamreza (2008) The Establishment of a comprehensive quality management system and its role in improving customer satisfaction "Case Study: Telecom Fars Province".

Sitkillkay, M., \& Aslan, E. (2012).The effect of the ISO 9001 quality management system on the performance of SMEs. International Journal of Quality \& Reliability Management, 29(7), 753-778.

Sitkillkay, M., \& Aslan, E. (2012).The effect of the ISO 9001 quality management system on the performance of SMEs. International Journal of Quality \& Reliability Management, 29(7), 753-778.

Tomic, B., Spasojc-Brkic,V., \&Klarin, M. (2012). Quality management system for the aerospace industry.

Torbica, z.m; stroh, r.c;.(1999). impact of total quality management on hom buyer satisfaction.journal of conztruction engineering and management,vol.125No.3, 198-203.

vroom, v; yetton, p;. (1973). lendership and decision making.university of pittsburgh press.

William M. "The management and control of Quality".)Evans,james R., Lindsay, (2008) 
Zeng, S. X., Tian, P., \& Tam, C. M. (2007).Overcoming barriers to sustainable implementation of the ISO 9001 system. Managerial Auditing Journal, 22(3), 244-254.

Zhang, Z., Song, T., \& Song, J. (2014).Analysis of Relationship between Quality Management System and Design Assurance System. Procedia Engineering, 80, 565-572. 